\title{
Hnútar í skjaldkirtli
}

\section{Geir Tryggvason ${ }^{1,2}$ læknir, Birgir Briem ${ }^{1}$ læknir}

\section{Á G R I P}

Hnútar í skjaldkirtli eru algengt vandamál og nýgengi peirra hefur aukist mikið. Kerfisbundin nálgun við uppvinnslu er nauðsynleg til að greining fáist fljótt en ekki síður til að̃ koma í veg fyrir ofgreiningu og ofmeðhöndlun sjúklinga. Pað er mikilvægt að nota hina svokölluðu prígreiningu, sögu/ skoðun, ómun og fínnálarástungu ásamt skjaldvakamælingu (TSH). Ómun af skjaldkirtli er lykilpáttur í uppvinnslu, par er mikilvægt að áhættuflokka hnúta, bað er eftir líkum á krabbameini, og pað er einnig mikilvægt við val á hnútum til að stinga, ef peir eru fleiri en einn. Ómun er einnig hjálpleg við ástungu, sérstaklega í hnútum sem ekki eru preifanlegir eða eru að hluta vökvafylltir. Kerfisbundið mat á frumusýnunum, flokkuðum eftir til dæmis Bethesda, er nauðsynlegt til að̃ einfalda samskipti meinafræðinga og klínískra lækna.

\section{Inngangur}

Hnútar í skjaldkirtli eru algengir og ef leitað er ítarlega finnast hnútar í yfir 50\% fullorðinna og eykst algengi hnúta með hækkandi aldri. ${ }^{1}$ Nýgengi skjaldkirtilskrabbameins hefur aukist undanfarin 20 ár. Spáð hefur verið að ef fram heldur sem horfir verði skjaldkirtilskrabbamein fjórða algengasta krabbameinsgreiningin í Bandaríkjunum árið 2030 (er nú 8. algengasta greiningin) og verði algengari en ristilkrabbamein. ${ }^{2}$ Pessi aukning finnst í öllum heimshlutum og sýna rannsóknir frá Bandaríkjunum³ ${ }^{3}$ Evrópu ${ }^{4}$ og Asíu ${ }^{5}$ aukið nýgengi af bæði totumyndandi- og skjaldbúskrabbameini. Prátt fyrir aukið nýgengi hefur dánartíðni ekki aukist. ${ }^{3}$ Skýringin á hækkuðu nýgengi felst meðal annars í pví að einkennalaus krabbamein finnast við myndgreiningar sem gerðar eru við önnur tilefni, svo sem tölvusneiðmynd af lungum, ómskoðun af hálsæðum og tölvusneiðmynd af hálshrygg við slys. ${ }^{6}$ Einnig hefur skimun í löndum á borð við S-Kóreu átt sinn pátt í nýgengnisaukningunni.?

Krufningarrannsóknir hafa sýnt að staðbundin, einkennalaus skjaldkirtilskrabbamein finnast í allt að 35\% einstaklinga. ${ }^{8}$ Pessi einkennalausu krabbamein eru pau æxli sem finnast í síauknum mæli og eru oft meðhöndluð á sama hátt og æxli sem hafa klíníska pýðingu. Gerð hefur verið framskyggn rannsókn par sem pessum illkynja æxlum $(<1 \mathrm{~cm})$ var fylgt eftir með ómskoðunum án nokkurrar meðferðar og kom í ljós að eftir 10 ár höfðu einungis $15 \%$ vaxið >3 mm. Einnig kom í ljós að horfur sjúklinga sem purftu á skurðaðgerð að halda seinna voru ekki verri. ${ }^{9}$ Pær klínísku leiðbeiningar sem finnast beggja vegna Atlantshafsins ${ }^{10,11}$ eru að mestu

1Háls-, nef- og eyrnaskurðdeild Landspítala Fossvogi, ${ }^{2}$ æknadeild Háskóla Íslands. Fyrirspurnum svarar Geir Tryggvason geirt@/sh.is

Höfundar hafa útfyllt eyðublað um hagsmunatengsı.

https://doi.org/10.17992//bl.2017.01.117 byggðar á rannsóknum á sjúklingum með einkenni og í dag er pví óljóst hvort vinna eigi upp einkennalausa sjúklinga á sama hátt og sjúklinga sem hafa einkenni. Petta gerir pað að verkum að mikilvægt er að ræða ítarlega við sjúklinga um kosti pess og galla að vinna upp litla hnúta í skjaldkirtli. Pað á sérstaklega við um eldri sjúklinga, með aðra sjúkdóma sem hugsanlega hafa verri horfur en skjaldkirtilskrabbamein. Með peirri greiningartækni sem notuð er í dag getur verið erfitt að skilja milli krabbameina sem munu liggja í dvala, án pess að purfa á meðhöndlun, og peirra sem vaxa ífarandi og/eða meinverpast. Pessi óvissa hefur í för með sér að nú fá margir sjúklingar meðhöndlun sem peir purfa hugsanlega ekki.

Раð er pó gott fyrir hinn almenna lækni að hafa ákveðinn ramma um hver skrefin eru í uppvinnslu á hnúti í skjaldkirtli. Í pessari grein munum við fara í gegnum pessa uppvinnslu með sérstaka áherslu á prígreiningu hnúta, pað er klíníska skoðun, ómskoðun og fínnálarástungu.

\section{Einkenni}

Fyrstu einkenni skjaldkirtilshnúta eru venjulega preifanleg fyrirferð neðarlega á hálsi. Mikilvægt er að spyrja um vaxtarhraða, eymsli og um einkenni skjaldkirtilsofstarfsemi og vanvirkni. Oft fylgja pó hnútum sem koma til mats lítil sem engin einkenni. Ef loftvegaeinkenni eru til staðar, svo sem erfiðleikar við öndun eða soghljóð (stridor), er hnúturinn venjulega stór eða að um ífarandi vöxt krabbameins er að ræða. Raddbandalömun með hæsi, kyngingarerfiðleikum (ásvelgingu) eða blóðhósta gefur til kynna vöxt út fyrir kirtilinn, í vélinda eða loftveg. Loftvegaeinkenni parf að meta fljótt, venjulega af sérfræðingi í háls-, nef- og eyrnalækningum. Einnig parf að hafa í huga að hratt vaxandi hnút, sérstaklega með verkjum, parf að vinna upp fljótt par sem mismunagreiningar geta verið alvarlegar, eins og villivaxtarkrabba- 
Tafla I.

\begin{tabular}{|c|c|c|}
\hline Flokkur & Ómútlit & $\begin{array}{c}\text { Líkur á } \\
\text { krabbameini \% }\end{array}$ \\
\hline $\begin{array}{l}\text { Mjög } \\
\text { grunsamlegur }\end{array}$ & $\begin{array}{l}\text { Ómdökkur hnútur með ein eða fleiri } \\
\text { útlitseinkenni: óreglulegar útlínur, } \\
\text { örkalkanir, hæð>breidd, brotin } \\
\text { randstæð kölkun eða vexti út fyrir kirtil }\end{array}$ & $>70-90$ \\
\hline Óljós grunsemd & $\begin{array}{c}\text { Ómdökkur, gegnheill hnútur án } \\
\text { örkalkana, vaxtar út fyrir skjaldkirtil eða } \\
\text { hæð>breidd }\end{array}$ & $10-20$ \\
\hline Lágur grunur & $\begin{array}{l}\text { Ómlíkur eða ómbjartur hnútur án } \\
\text { örkalkana, óreglulegri útlínu, vaxtar út } \\
\text { fyrir skjaldkirtil eða hæð>breidd }\end{array}$ & $5-10$ \\
\hline $\begin{array}{l}\text { Mjög lágur } \\
\text { grunur }\end{array}$ & $\begin{array}{l}\text { Svamplíkt útlit, misleitur hnútur að̃ hluta } \\
\text { til með blöðru, án útlits sem lýst er í } \\
\text { ofannefndum flokkum }\end{array}$ & $<3$ \\
\hline Góðkynja & Hrein blaðra & $<1$ \\
\hline
\end{tabular}

Ómflokkun klínískra leið̌beininga amerísku skjaldkirtilsamtakanna. ${ }^{10}$

mein (anaplastic carcinoma) eða eitlakrabbamein, pó blæðing inn í góðkynja hnút komi líka til greina.

\section{Áhættupættir}

Mikilvægt er að spyrja um pekkta áhættupætti skjaldkirtilskrabbameins. Pað getur breytt nálgun læknis við uppvinnsluna og ekki síst ákvörðun um aðgerð.

Ef fjölskyldusaga er um skjaldkirtilskrabbamein er allt að preföld áhætta á að hnútur sé illkynja ef náinn ættingi hefur verið greindur með sjúkdóminn. Pví yngri sem sjúklingur er við greiningu skjaldkirtilskrabbameins, peim mun meiri aukning á nýgengi í nánum ættingjum. ${ }^{12}$ Hashimotos-skjaldkirtilsbólga er áhættupáttur fyrir totumyndandi skjaldkirtilskrabbameini. ${ }^{13}$ Mikilvægt er að fá fram sögu um erfðaheilkenni hjá sjúklingi eða ættingjum pví Cowden, Werner, Carneys-einkennaflækja og Garners-heilkenni gefa aukna áhættu á ekki-merggerðar skjaldkirtilskrabbameini en MEN-heilkenni 2A og 2B gefa aukna áhættu á merggerðar krabbameini. ${ }^{14}$

Geislun á háls er einnig áhættupáttur. Geislunin parf að hafa átt sér stað fyrir tvítugsaldur eins og rannsóknir eftir kjarnorkusprengjurnar í Hiroshima og Nagasaki og slysið í Tjernobyl, hafa sýnt fram á og pví yngri sem einstaklingurinn er við geislunina, peim mun meiri áhætta. ${ }^{15}$ Petta á líka við um geislameðferð hjá börnum og á síðari árum hafa komið fram vísbendingar um lítilsháttar aukna áhættu hjá fólki sem hefur verið gerð sneiðmyndataka hjá á barnsaldri. ${ }^{16}$

\section{Blóðprufur}

Eitt pað fyrsta sem parf að gera hjá sjúklingi með hnút í skjaldkirtli er að mæla skjaldvakakveikju (TSH). Gildið stýrir næstu skrefum uppvinnslunnar. Ef TSH er lágt er uppvinnsla að mestu í höndum innkirtlasérfræðinga par sem pá er um að ræða skjaldkirtilsofstarfsemi og líkurnar á krabbameini í peim hnútum eru litlar. Sé

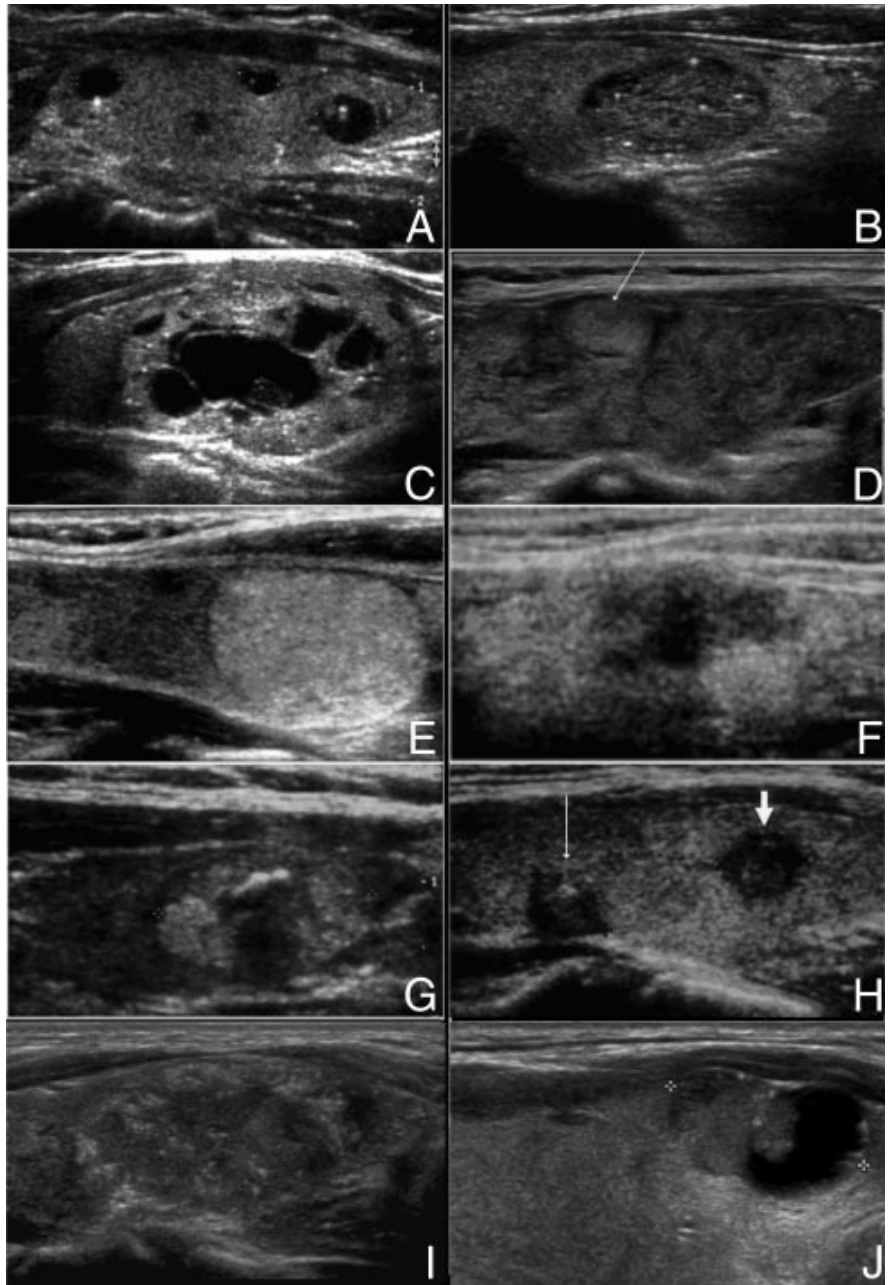

Mynd 1. Ómmyndir af skjaldkirtli með ýmsa meinafræði. A: Margar kvoðulausnarblöðrur (colloid cyst) með björtum punktum sem hafa stjörnuhala (comet-tail). B: Önnur gerð af kvoðulausnarblöðru. C: Priðja gerðin af kvoðulausnarblöðru. D: Ómmynd af Hashimotos-skjaldkirtilsbólgu par sem örin bendir á gervihnút (pseudo-nodule) E: Hnútur sem er ómbjartari (hyperechoic) en kirtillinn sjálfur með geislabaug (halo). F: Hnútur sem er ómdekkri (hypoechoic) en kirtillinn sjálfur með illa sjáanlegar útlínur. G: Hnútur sem er misleitur með kalki og pykku hýði (capsule). H: Tveir hnútar, báðir ómdökkir með illa sjáanlegar útlínur með (mjó ör) og án (breið ör) kalkana. I: Gegnheill, ómlíkur (isoechogenic) hnútur með illa skilgreindar útlínur og örkalkanir. J: Hnútur með blandað ómútlit, án geislabaugs og með örkalkanir.

Endurprentað með leyfi The Endocrine Society. Birtist ádur í Journal of Endocrinology and Metabolism árið 2009. ${ }^{21}$

TSH eðlilegt eða hátt er næsta skref ómskoðun. Ekki er mælt með reglubundinni mælingu kalsítóníns. ${ }^{10}$

\section{Myndgreining - ómskoðun}

Ómskoðun er mikilvæg í uppvinnslu hnúts í skjaldkirtli. Háskerpuómskoðun er mun betri en tölvusneiðmynd eða segulómskoðun í að meta hvern hnút fyrir sig og meta pannig líkur á krabbameini. Раð eru ýmsir pættir sem hægt er að meta með ómun en ekkert eitt útlitseinkenni er sjúkdómsgreinandi fyrir krabbamein. Annar kostur ómskoðunar er að samtímis er hægt að gera ómstýrða fínnálarástungu til að fá frumusýni til mats af meinafræðingi. Par sem hnútar í skjaldkirtli eru algengir og fæstir eru illkynja, parf kerfi til að velja hnúta til ástungu. Hætta er á ofgreiningu ef stungið væri á öllum hnútum sem sæjust við ómun 


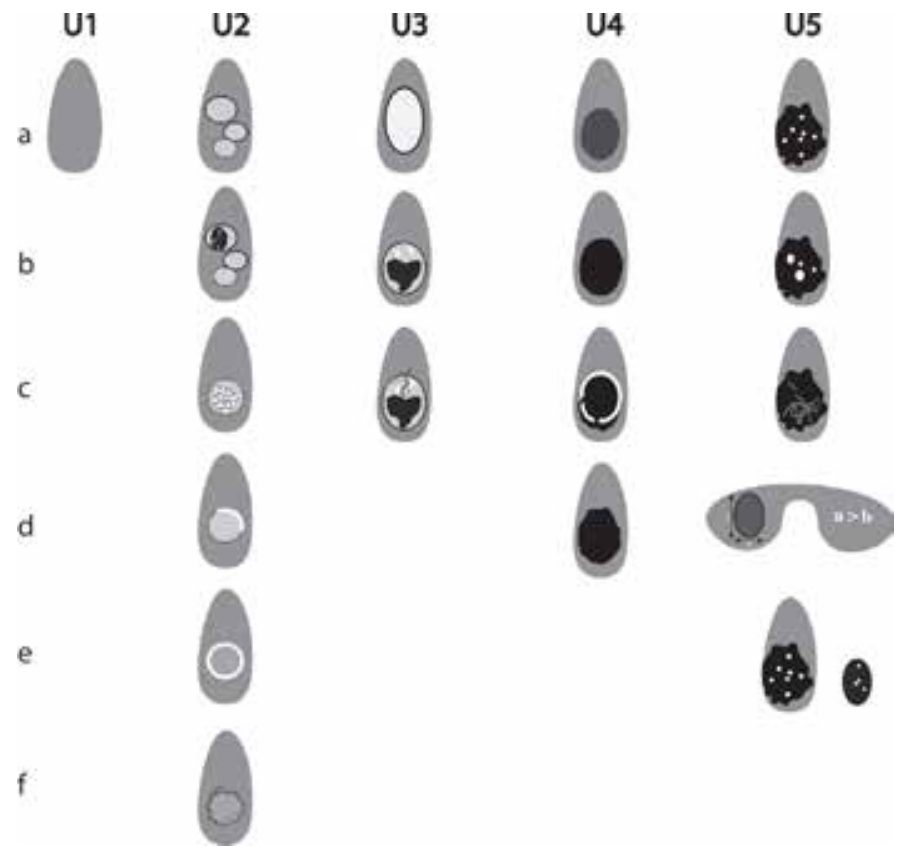

Mynd 2. Ómflokkun bresku skjaldkirtilssamtakanna. U1: Eðlilegur skjaldkirtill. U2: Góðkynja útlit -a) geislabaugur, ómlíkurlómbjartur. b) blöðrubreyting, stjörnuhali. c) örblöðrur, svamplíkur. d) og e) randstæð kölkun f) randstætt blóðflæði. U3: Óljóst útlit: a) einsleitur, mjög ómbjartur, gegnheill, geislabaugur. b) blöðrubreyting, óljósir ómríkir punktar. c) misleitt eða miðstætt blóðflæði. U4: Grunsamlegt útlit. a) gegnheill, ómdökkur. b) gegnheill, mjög ómdökkur c) brotin randstæð kölkun, ómdökkur. d) bleðillíkar (lobulated) útlínur. U5: Krabbameinsútlit. a) gegnheill, ómdökkur, óregluleg útlína, örkalkanir. b) gegnheill, ómdökkur, óregluleg útlína, stærri kalkanir. c) miðstætt blóðflæði d) lögun, hæð>breidd e) grunsamlegir eitlar.

Endurprentað með leyfi Wiley Company, birtist áður í Clinical Endocrinology árið $2014 .^{11}$

eins og klárlega sést í skipulagðri skjaldkirtilsskimun í S-Kóreu. ${ }^{7}$ Вæði er pað tímafrekt og kostnaðarsamt og ekki minnst eru pað ópægindi fyrir sjúklinginn með ónauðsynlegum rannsóknum og töluverðri hættu á ofgreiningu og ofmeðhöndlun.

Nýjustu leiðbeiningar amerísku skjaldkirtilssamtakanna frá 2016 mæla ekki með sýnatöku frá hnútum $<1$ cm nema í sérstökum tilvikum. ${ }^{10}$ Par er einnig mælt með óm-áhættumati sem samsvarar að miklu leyti áhættumati í nýjustu klínísku leiðbeiningum bresku skjaldkirtilssamtakanna frá 2014 par sem farin er sú leið að flokka hnúta í 5 áhættuflokka frá U1-U5 (mynd 2). ${ }^{11}$ Ef hnútar falla í áhættuflokk 1 og 2 (U1 og U2) er ekki ástæða til að taka sýni en ef hnútar falla í flokk 3-5 (U3-U5) er ráđlagt að taka fínnálarsýni. Tillaga að verklagi er gefin í mynd 3. Hér parf að hafa í huga að ef hnútur er grunsamlegur á ómskoðun en fínnálarsýni gefur til kynna góðkynja hnút pá parf að endurtaka sýnatöku.

Útlitseinkenni skjaldkirtilshnúta við ómskoðun og tengsl við krabbamein Рað eru ýmis útlitseinkenni sem geta bent til krabbameins við ómskoðun og önnur sem benda til góðkynja hnúts. Kwak og félagar ${ }^{17}$ gerðu rannsókn á 2000 skjaldkirtilshnútum sem höfðu verið metnir með ómskoðun og bjuggu til áhættuskor par sem eftirfarandi útlitseinkenni: ómdökkur (2), mjög ómdökkur (6), lögun (hæð >breidd) (1), örbleðlaður (microlobulated) eða gaddaður (spiculated) (5), illa afmarkaður (1) og örkalkanir (2) voru notuð og síðan lögð saman. Pá fékkst stigull par sem 0 stig gáfu $6 \%$ líkur á krabba-

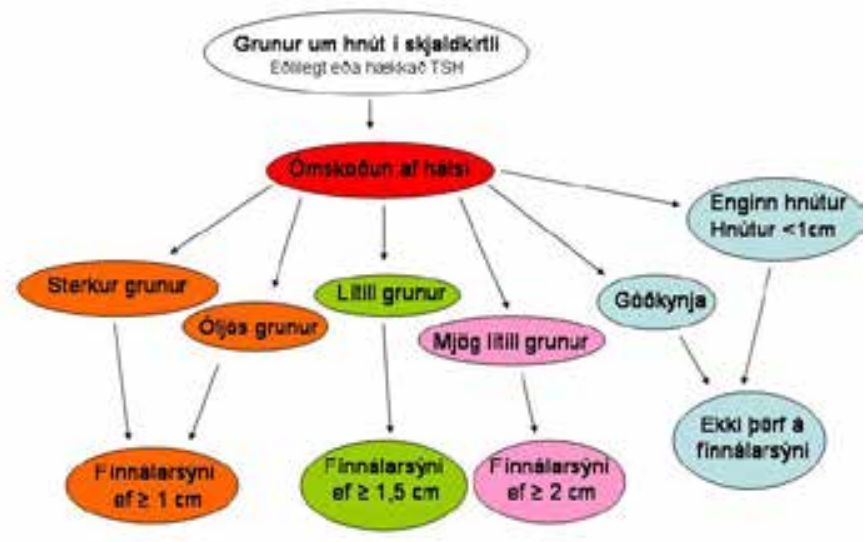

Mynd 3. Flæðirit fyrir uppvinnslu hnúts í skjaldkirtli. Byggt á mynd úr leiðbeiningum amerísku skjaldkirtilssamtakanna. ${ }^{10}$

meini og 14 stig 90\% líkur á krabbameini. Petta er tiltölulega einfalt kerfi í notkun og gæti gagnast við klíníska vinnu. Ein pýðisrannsókn frá San Francisco ${ }^{18}$ er líklega pað einfaldasta í notkun en par slógu út pættirnir: stærð $>2 \mathrm{~cm}$, örkalkanir og gegnheill hnútur. Ef einn páttur er til staðar pyrfti 56 ástungur til að finna eitt krabbamein og ef tveir pættir eru til staðar pá pyrfti einungis 16 ástungur til að finna eitt krabbamein pó á kostnað næmis (sensitivity) sem var einungis 52\%. Áhættumatið sem maður fær með ómskoðun getur hjálpað til við að velja hnúta til ástungu ef til staðar eru margir hnútar. Bresku skjaldkirtilssamtökin hafa tekið upp ómskoðunaráhættugreiningu hnúta í sínar leiðbeiningar. ${ }^{11}$ Petta kerfi gagnast í klínískri vinnu pví pað er einfalt, setur hnúta í flokka sem er auðvelt að vinna með og hjálpar til við val á hnútum til ástungu og ekki síst val á hnútum sem ekki skal stinga á (mynd 2). Petta kerfi líkist pví kerfi sem sett er fram í nýlega birtum leiðbeiningum amerísku skjaldkirtilssamtakanna. ${ }^{10}$ Í pví áhættuflokkunarkerfi eru 5 flokkar, frá góðkynja upp í illkynja (tafla I). •að fer síðan eftir pví hvar hver hnútur lendir í peim flokki hvað ráðlagt er að gera. Farið er yfir hverju mælt er með í mynd 3.

Pað eru til mörg flokkunarkerfi sem hægt er að nota við ómskoðanir en ekkert eitt er afgerandi best. Næmi og sértæki er mismunandi fyrir hvert og eitt en mikilvægast er að sá sem framkvæmir rannsóknina hafi reynslu í að meta ofannefnda pætti pannig að skoðunin leiði til sýnatöku ef við á.

Á síðari árum hefur sú próun orðið að ómskoðanir eru æ oftar framkvæmdar af skurðlæknum og innkirtlalæknum sem meðhöndla skjaldkirtilskrabbamein. Röntgenlæknar eru pó enn peir sem framkvæma flestar rannsóknir. Í okkar huga er mikilvægt að sá sem framkvæmir ómskoðun af skjaldkirtli hafi reynslu í mati á hnútum og pekkingu í ómáhættuflokkun ásamt pví að hafa hlotið pjálfun í að gera fínnálarástungur á skjaldkirtli gerist pess pörf.

\section{Fínnálarsýni}

Pað sem er mikilvægt við fínnálarsýnatöku af hnútum í skjaldkirtli er að velja hnútana rétt. Ekki parf að taka sýni af öllum hnútum. Eins og nefnt var að ofan hjálpar ómskoðun mikið við val á hnútum til ástungu. Pegar ákvörðun hefur verið tekin um að taka sýni er mikilvægt að nota rétta tækni pví oft gengur ekki að nota sömu tækni við fínnálarástungu á skjaldkirtli og notuð er við aðra hnúta 
Tafla II. Bethesda-kerfið fyrir greiningu á fínnálarsýni frá skjaldkirtli. ${ }^{19}$

\begin{tabular}{ccc}
\hline & Greiningarflokkur & Líkur á illkynja æxli \% \\
\hline 1 & Ekki greiningarhæft sýni & $1-4$ \\
\hline 2 & Góđkynja & $0-3$ \\
\hline 3 & Afbrigði $^{\star}$ & $5-15$ \\
\hline 4 & Skjaldbús æxli & $15-30$ \\
\hline 5 & Grunsamlegt fyrir illkynja æxli & $60-75$ \\
\hline 6 & Illkynja æxli & $97-99$ \\
\hline
\end{tabular}

*Á ensku: Atypia of undetermined significance or follicular lesion of undetermined significance.

á hálsi. Ómstýrð ástunga hjálpar líka við að hitta á réttu svæðin innan hnútsins, til dæmis að hitta gegnheila hluta hnúts sem er að hluta fylltur vökva. Samskipti á milli peirra lækna sem meðhöndla sjúklinga og meinafræðings purfa að vera skýr og pað parf að vera klárt hvað pað pýðir sem kemur fram í svari meinafræðings pví pað stýrir næstu skrefum uppvinnslu, meðferðar og eftirfylgni.

Flokkun frumusýna í kerfi, til dæmis Bethesda-kerfið, er mikil framför par sem reynt er að staðla svör pannig að samskipti meinafræðings og meðhöndlandi læknis séu eins skýr og hægt er. ${ }^{19}$ Petta kerfi er sett upp í töflu II. Meðhöndlandi læknar purfa pó að hafa í huga að Bethesda-flokkarnir geta haft mismunandi líkur á krabbameinsgreiningu milli frumumeinafræðinga eða sjúkrahúsa og pví mikilvægt að hafa hugmynd um pær líkur sem gilda hjá peim meinafræðingi sem maður sendir sýni til.

Helsta vandamálið við petta kerfi eru flokkar 3 og 4 sem mörg sýni lenda í. •að getur verið erfitt að leiðbeina sjúklingi með næstu skref hafni hnútur í pessum flokkum enda eru pá einhverjar líkur á krabbameinsgreiningu og sjúklingar misjafnlega undir pað búnir að óvissa ríki um greininguna. Oft verður lendingin sú að við Bethesda 3 er sýnataka endurtekin eftir ákveðin tíma og við Bethesda 4 er mælt með skjaldhelftarnámi að jafnaði. Nú er að ryðja sér til rúms greining á sameindavísum á nálarsýnum og pað mun verða mjög hjálplegt við að skilja á milli peirra hnúta sem ætti að fjarlægja í aðgerð og peirra sem ætti að fylgja með ómskoðunum. ${ }^{20}$

\section{Niðurlag}

Hnútar í skjaldkirtli eru algengt vandamál og nýgengi peirra hefur aukist mikið og mun aukast enn frekar á næstu árum. Kerfisbundin nálgun við uppvinnslu er nauðsynleg til að greining fáist fljótt en ekki síður til að koma í veg fyrir ofgreiningu og ofmeðhöndlun sjúklinga. Ómun er nauðsynlegur hluti af uppvinnslu hnúta, ekki síst til að áhættugreina hnúta og velja hnúta til fínnálarsýnatöku. Kerfisbundið mat á frumusýnunum par sem pau eru flokkuð, til dæmis eftir Bethesda-flokkunum, er nauðsynleg til að einfalda samskipti meinafræðinga og klínískra lækna.

\section{Heimildir}

1. Ezzat S, Sarti DA, Cain DR, Braunstein GD. Thyroid incidentalomas. Prevalence by palpation and ultrasonography. Arch Intern Med 1994; 154: 1838-40.

2. Rahib L, Smith BD, Aizenberg $R$, Rosenzweig $A B$, Fleshman JM, Matrisian LM. Projecting cancer incidence and deaths to 2030: the unexpected burden of thyroid, liver, and pancreas cancers in the United States. Cancer Res 2014; 74: 2913-21.

3. Davies L, Welch HG. Current thyroid cancer trends in the United States. JAMA Otolaryngol Head Neck Surg 2014 140: 317-22.

4. Londero SC, Krogdahl A, Bastholt L, et al. Papillary thyroid carcinoma in Denmark 1996-2008: an investigation of changes in incidence. Cancer Epidemiol 2013; 37: e1-6.

5. Burgess JR. Temporal trends for thyroid carcinoma in Australia: an increasing incidence of papillary thyroid carcinoma (1982-1997). Thyroid 2002; 12: 141-9.

6. Davies L, Ouellette M, Hunter M, Welch HG. The increasing incidence of small thyroid cancers: where are the cases coming from? Laryngoscope 2010; 120: 2446-51.

7. Ahn HS, Kim HJ, Welch HG. Korea's thyroid-cancer "epidemic"--screening and overdiagnosis. N Engl J Med 2014; 371: 1765-7.

8. Harach HR, Franssila KO, Wasenius VM. Occult papillary carcinoma of the thyroid. A "normal" finding in Finland. A systematic autopsy study. Cancer 1985; 56: 531-8.

9. Ito $Y$, Miyauchi $A$, Inoue $H$, Fukushima $M$, Kihara $M$ Higashiyama T, et al. An observational trial for papillary thyroid microcarcinoma in Japanese patients. World J Surg 2010; 34: 28-35.
10. Haugen BR, Alexander EK, Bible KC, Doherty GM, Mandel SJ, Nikiforov YE, et al. 2015 American Thyroid Association Management Guidelines for Adult Patients with Thyroid Nodules and Differentiated Thyroid Cancer: The American Thyroid Association Guidelines Task Force on Thyroid Nodules and Differentiated Thyroid Cancer. Thyroid 2016; 26: 1-133.

11. Perros P, Boelaert K, Colley S, Evans C, Evans RM, Gerrard Ba G, et al. Guidelines for the management of thyroid cancer. Clin Endocrinol 2014; 81: Suppl 1:1-122.

12. Fallah M, Pukkala E, Tryggvadottir L, Olsen JH, Tretli S, Sundquist K, et al. Risk of thyroid cancer in first-degree relatives of patients with non-medullary thyroid cancer by histology type and age at diagnosis: a joint study from five Nordic countries. J Med Genet 2013; 50: 373-82.

13. Kim KW, Park YJ, Kim EH, Park SY, Park do J, Ahn SH, et al. Elevated risk of papillary thyroid cancer in Korean patients with Hashimoto's thyroiditis. Head Neck 2011; 33: 691-5.

14. Richards ML. Thyroid cancer genetics: multiple endocrine neoplasia type 2, non-medullary familial thyroid cancer, and familial syndromes associated with thyroid cancer. Surg Oncol Clin N Am 2009; 18: 39-52, viii.

15. Furukawa $K$, Preston D, Funamoto S, Yonehara S, Ito $M$ Tokuoka S, et al. Long-term trend of thyroid cancer risk among Japanese atomic-bomb survivors: 60 years after exposure. Int J Cancer 2013; 132: 1222-6.
16. Mathews JD, Forsythe AV, Brady Z, Butler MW, Goergen SK, Byrnes GB, et al. Cancer risk in 680,000 people exposed to computed tomography scans in childhood or adolescence: data linkage study of 11 million Australians. BMJ 2013; 346: f2360.

17. Kwak JY, Jung I, Baek JH, Baek SM, Choi N, Choi YJ, et al. Image reporting and characterization system for ultrasound features of thyroid nodules: multicentric Korean retrospective study. Korean J Radiol 2013; 14: 110-

18. Smith-Bindman R, Lebda P, Feldstein VA, Sellami D, Goldstein RB, Brasic N, et al. Risk of thyroid cancer based on thyroid ultrasound imaging characteristics: results of a population-based study. JAMA Intern Med 2013; 173: 1788-96.

19. Cibas ES, Ali SZ. The Bethesda System for Reporting Thyroid Cytopathology. Thyroid 2009; 19: 1159-65.

20. Witt RL, Ferris RL, Pribitkin EA, Sherman SI, Steward DL, Nikiforov YE. Diagnosis and management of differentiated thyroid cancer using molecular biology. Laryngoscope 2013; 123: 1059-64.

21. Horvath E, Majlis S, Rossi R, Franco C, Niedmann JP, Castro A, et al. An ultrasonogram reporting system for thyroid nodules stratifying cancer risk for clinical management. J Clin Endocrinol Metab 2009; 94: 1748-51. 


\section{ENGLISH SUMMARY}

\section{Evaluation of a thyroid nodule}

Geir Tryggvason ${ }^{1,2}$, Birgir Briem ${ }^{1}$

Thyroid nodules are common and their incidence has increased due to various factors. Systematic approach to the work-up of thyroid nodules is necessary to decrease overdiagnosis as well as over treatment. Applying the trifecta of history, physicial examination and high-resolution ultrasound (HRUS) as well as fine needle aspiration biopsy (FNAB) with

added TSH measurement is important in the work-up. HRUS is a central part in the diagnostic approach, being able to risk classify nodules and selecting nodules for FNAB. Systematic analysis of aspirates is necessary to simplify communication between cytologists and clinicians.

${ }^{1}$ Department of Otolaryngology - Head and Neck Surgery, Landspitali, Fossvogi, ${ }^{2}$ Department of Medicine, University of Iceland.

Key words: thyroid nodule, thyroid cancer, ultrasound, cytology

Correspondence: Geir Tryggvason, geirt@/sh.is 